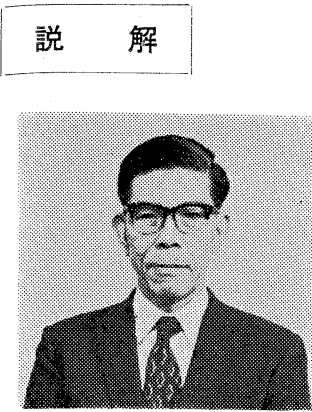

\title{
低温工学と水 素*
}

\author{
神蜀英蔵 \\ 日本大学生産工学部 習志野市泉町
}

(1973年 9 月 6 日受理)

\section{"Hydrogen in Cryogenic Engineering"}

\section{by Eizo KANDA}

College of Industrial Technology, Nihon University, Izumicho, Narashino

(Received September 6, 1973)

\section{Synopsis :}

Hydrogen is now expected to have great needs as clean fuel and as energy reservation and transportion medium. In connection with this prospect, several researches in physical chemistry and chemical engineering with hydrogen are reviewed which have been done by the author's group in the Cryogenic Laboratory in Tohoku University. Recent researches on some materials concerning the hydrogen problem are also mentioned. Importance of researches and developments in cryogenic engineering with hydrogen is stressed.

\section{1. 水素の將来の用途}

最近化石エネルギ一資源の先細りの見とおし，環境 污染の拡大と深刻化, それに多分アメリカでの NASA の宇宙事業の発展にともなった液体水素の工学的，技 術的進歩などが原因となって，エネルギーシステムと しての水素の重要性が盛んにとなえられてきた。これ については寸でに太田時男氏日 や，菊地一成氏 ${ }^{2)} ら ゙^{1)}$ 本誌に寄稿されているので,ここに再言するを要しな いが，談を進める都合上ごく簡単にふれておく。

a）冷媒としての液体水素

今日の超伝導体で液体水素の低温度に使えるものは ない。したがって送電線として超伝導ケーブルではな く, $\mathrm{Al}$ や $\mathrm{Cu}$ の純度の高いケーブルを液体水素温度 でいわゆるクライオケーブルとして用いるのも現実的 な考え方であろう。実際, 冷涷機の所要馬力は液体水 素温度と液体へリウム温度とでは 1:7 の比になるこ と，また水素とへリウムのリットルあたりの蒸発潜熱 がそれぞれ約 1.5 キロカロリーと 0.7 キロカロリーに

Vol, 8 No. 5 (1973)
なることを考えれば，必ずしも液体へリウム温度のみ が良いわけではない。冷凍能力の点からは，せめて， 液体水素温度（三重点までの低温度字ふくめて）で用 いらる超伝導体の開発（もし可能ならば）が切望され る。これは後にも少しくふれるが，かなり困難視され るが，もしも実現すれ壮影響するところのきわめて大 きいものである。

冷涷能力の大きさの他に，へリウムガス資源の問題 が，ちょうど化石燃料資源と同じような段階をとるの ではなからうか。すなわち，今のところなんとか不自 由はないし, 今後も新しい探鉱の成果があがろらが, いずれは経済性の悪い大気からの採集に頼ら枚ばなら ぬ運命にある。（もっとも，重水素の核融合がエネル ギ一源として実用になり，どんどん $\mathrm{He}$ が副次的に生 産されれば別である。

b) き机いな然料としての水素

* 第11回低温工学研究発表会（昭和 48 年 5 月, 仙 台)に打ける特別講演をもとにした。したがって 講演の形式をとどめているのを諒承されたい。 
経済性の点では，地中から掘り出せばいわばそのま ま然料になる石油や天然ガスにはかなわないが，水素 と酸素を反忘させてまた自然の水にもどすサイクル は，究極的には自然にさからわない，環境污染のない エネルギーシステムであろう。水素をうむために天然 エネルギー源たる太陽熱を使うとする，たとえば大田 氏らの案は，経済性は別として，いわ壮太陽系の中の 一員として永く生きる唯一つの方法であろう。然料 使用の末端装置としてのバーナ一や水素酸素系の燃料 電池において水素を用いる他に，エネルギー材料の貯 蔵や輸送の手段としての水素は比較的間近に使われる ものではなかららか。余剩電力で水素然料をつくって 貯えておく（液体水素タンクに）ことは，蓄電池や超 伝導コイルなどに代るすぐれた方法であろら。また電 力輸送方法が大電力時代を見こして, 困難な超伝導ケ 一ブルさえ計画され出した今日, エネルギー媒体とし て水素を液体または気体で管送する方法は, 前記の超 伝導送電に対置して重大に考えられねばならないだろ ら。究極的なエネルギー源は何であれ, エネルギ一担 体としての水素を運ぶことは今すぐにでも研究される ベきであろう。

\section{c）水素推進浏}

“きれいな燃料”としての他に同じく然料としてで あるが，ロケットエンジンの推進剤としての水素の優 秀性も早くから唱えられてきている。液体水素の取扱 いにともなら困難さから，なかなか一般のロケットエ ンジンには利用されないで, 経済性を無視して技術の 粋をあつめられる宇宙飛行のロケットにのみ応用され てきたが, 低温工学的開発を進めて, 一般の航空機に もいずれは用いられるものであろら。

d）核融合反応が実用になる場合

これはその成功の時期は先へ先へと延ばされてい る。資源の無尽蔵の水から採取できる重水素が融合反 応物質になること, その重水素の製造プロセスの一つ として後述の水素の液化精溜が一つの有力な手段であ ることは, 低温工学の対象として重視してよいであろ 5 。

大体以上の上らな将来が水素の用途として期待でき る。これの実現の時期は上記の事項によって若干相違 はあろう。特に核融合のように科学と技術が成功する ことが必要条件になる他に, 案外重要なのは社会経済 的および社会心理的問題がある。すなわち，石油など の化石然料の欠之あるいは欠乏感の急迫と, 従来の燃 料使用による公害による被害感の増大の他に，水素に
対する爆発の危険感がある。こういった社会感情はお そらく重大な因子となってからみ合い，それぞれの因 子の生長, 減衰が水素をエネルギーシステムに取り入 れる時期を決定するであろう。

\section{2. われわれの液体水素の経験}

東北大学金属材料研究所では, 現在の液体へリウム 温度での研究の前に, 液体水素支用いての研究の時代 があった。これはもちろんアメリカの NASA におけ るような雄大な液体水素の用途を礼らってではない。 ましてやここにいら水素のエネルギージステムを考え てではない。しかし，液体へリウムが手に入るまでの ある期間，かなり熱心に液体水素を用いての研究が行 なわれたことは，世界的にもめずらしいことで，今か らみれば将来の水素時代の科学技術に寄与することに なった。その意味で，かなり以前のことであるがこれ を今日回雇頁する意義があると考えている。

a) 水素の液化

1931年にドイツの八イランド社から水素液化機が輸 入された。当㭙としては大変めずらしい低温装置であ ったわけで，液体空気より低い温度をつくる装置とし ては日本ではじめてのものである。水素ガス $100 \mathrm{~m}^{3} /$ hr, 最高 170 at の水素圧縮機を用いるリンデ方式の もので，もちろん液体窒素で予冷する。6l/hr の液化 能力をもつ。原料の水素ガスは純度の点を考えて, 水 の電解によって研究所内で製造した。爆発の危険は始 終念頭にあって,大学を卒業したばかりの門奈さん(現 在日本酸素) たちがはじめて運転したものである。こ の液化機䘮用いて, 後述の若干の実験研究を行なった が，今から思えば決して能率の良い液化機ではなく， 装置全体として図体の大きな割合には液化量と運転継 続時間は少なく，今から思えば正に低温科学時代の極 く初期のものといえる。後述するよらに後年われわれ は液化機本体を作り直して, 一躍 $25 i / \mathrm{hr}$ のものを得 た。しかしこのように, 外国からの装置の欠点を補っ たり改造したりする能力は, 当時の日本の大学のわれ われ，あるいは会社の技術としては成長していなかっ た。

\section{b) 固体水素}

液体水素を用いての实験にとりかかって間もなく, これで最低温度を得る目的で, 液体水素の排気低圧に よって水素の三重点を得た。簡単に水素の slush を得 た。それまでに酸素の三重点, 窒素の三重点を得て, ヘリウムガス寒暖計を用いて温度定点索定めた。液体 
ヘリウムを得られないのでなんとかその温度に近ゔく ために, 水素の三重点で活性炭にへリウムガスを等温 吸着させ，これを断熱脱着させることを試みた。低温 の実験を始めて数年で, 全く我流で実験を進めている 者によってこれはやさしい実験ではなかったが，遂に は $6^{\circ} \mathrm{K}$ に到達した ${ }^{3)}$ 。しかし，この温度で他の試料を 冷却して試験寸るには到底至らなかった。後年オック スフォード大学の Simon 教授から, 同じような手段 でヘリウム温度を得る方法を教えられたが，その時は われわれも近くへリウム液化機を設備することになっ ていたので，それを実行する必要はなかった。このよ らに液体, 固体の水素にしたしんでいるうちに, 最初 に恐れていた程は水素を危険視することはないと思ら ようになり，後年液体へリウムを用いるようになって も, 酸素や水素の凝縮状態の物性の研究に愛着在もつ ようになった。

c）液体水素と固体フッ素との爆発反応 ${ }^{4}$

フッ素は非常に化学的に活性な物質で取り扱いにく く，正確な物性のわかっていない元素であった。今日 では $\left(\mathrm{H}_{2}+\mathrm{F}_{2}\right)$ 系は口ケット推進剤として最も效率の 良いものの一つとされ，またフッ素の化合物には種々 の有用なものがあってその研究は盛んである。筆者は 液体空気や液体水素の温度で幾分反応性をよわめた領 域でフッ素の物性をいろいろしらべていたが，その中 で「液体水素と固体フッ素が接触すれば爆発する」と の古い文献をみて確かめ，かつその「接触するだけで 爆発する」不可解を究めたくなった。このために，1l ほどの液体水素をいれたデュワ一㼛の中に，5cc あま りの固体フッ素を凝縮した硝子球をつるし，この硝子 器を離れた場所から操作してこわして, フッ素し水素 との接触を試みた。硝子器がこわれたトタンに猛烈な 爆発がおこった。もちろん二次的に水素上空気中の酸 素との爆発反応も抽ったであろらが，デュワ一瓶は もちろん，金属製の付属の部品もこわれてしまって， 要するに液体水素と固体フッ素がふれ㐌うだけで爆発 反応をひきおこすことはハッキリ確かわた。しかし， なか壮爆発を期待しての，そのために危険を防止しな がらの奏験ではあったが，特に防爆壁索設けての試み でもなかった。自分としては一 $252^{\circ} \mathrm{C}$ のらな低温で 単なる接触だけで固体フッ素と液体水素が爆発するこ とは矢張り不问解であった。そのメカ二ズムを研究す るのが目的であったが, 液体水素 $1 l$ の爆発のはげし さに压倒されてあとをつづけられなかった。ついでな がら，凝縮系での爆発（たとえばアセチレンや濃縮液

Vol. 8 No. 5 (1973)
体オゾンの爆発など）は低温の実験をして経験したこ とがあるが，起爆のメカニズムはほんとうにはやはり わかっていない。

d) $\mathrm{Ne}$ 亡 $\mathrm{He}$ の分離

1935年頃から，国内に（といらよりか軍需的に） Ne ガスの需要が生じた。従来の輸入がとまったためかも しれない。日本電気から長崎準一氏が派遣されてこの 問題に取りくんだ。金属材料研究所には水素の液化機 設置の数厅月前に,リンデ式の空気液化分離装置がAir Liquid 社から輸入設備された。液体窒素を $25 \mathrm{l} / \mathrm{hr}$, 酸素ガス $60 \mathrm{~m}^{3} / \mathrm{hr}$ の製造量で, 液体窒素はもちろん われわれの低温実験用に, 酸素ガス注副産物だが酸素 会社に払下げ売却していた（大学で製品を契約して民 間に売却するまれな例であった)。この空気精溜塔の 部分から比較的 $(\mathrm{He}+\mathrm{Ne})$ をふくむ空素ガスをとり 出し, 活性炭吸着によって窒素を除去して $(\mathrm{Ne}+\mathrm{He})$ 混合ガスを数 $l /$ 月程度生産供給していた。そのうち $\mathrm{Ne}$ と $\mathrm{He}$ を分離する必要が生じて, 液体水素温度で $\mathrm{Ne}$ を凝縮捕集した。これは必ずしも液体水素温度を 要しないで, 窒素温度での活性炭吸着ででもよかった が，なにしろ少量のガスを大切に捕集するためと，当 時低温での加圧, 減圧が大儀であったので上記の方法 をとった。一つには低温での混合ガスの吸着平衡, 吸 着分離を系統的に研究する気運も余裕もなかったせい でもある。なお $(\mathrm{Ne}+\mathrm{He})$ 混合ガスではないが，こ れ以前にへリウムガス寒暖計を作ったが，このときの $\mathrm{He}$-ガス約 $1 l$ は, チヤバザイト鉣石を灼いて $\mathrm{He}$ を 追い出し, やはり液体水素孛用いて不純ガス（空気な どの）を凝固させて精製して用いた。

e ）重水素の採集

以上の諸種の研究は 1931 年から 1946 年頃までの約 15年間に行なわれたもので，もちろんこの間に液体水 素温度での物性的研究を進めるかたわらでの比較的水 素の低温工学に関係のありそうな研究を述べた。その 後, 戦争が終ってからへリウム液化機がわが国ではじ めて金属材料研究所に設置された。アメリカの ADL 社のもので, その後数年にして同様の装置は他の大学 にもボチボ千設倩され出して, 今日の盛況に至ってい る。それ以来，われわれは殆んどへリウム温度におけ る物性の研究を進めて今日に至っているが，その間 1955年頃わが国でも原子力利用の問題が出てから，重 水型原子炉用の重水の多量生産が問題になった。原子 力委員会あるいは原子力局の要請で, 各種の方法で重 水または重水素の製造試験を試みることになった。そ 
のうちの有力な方法として水素ガスの液化精溜法があ るが，当時は危険な水素を液化し，精溜することの可 能性あるいは実用性は非常に疑われていたと思う（情 報の不十分なこの頃, わが国では)。それで, 従来から 液体水素を実験的泟扱っていたのはわれわれのところ だけであったので，この研究を引き受けることになっ た。今日日立中研に㧍られる佐藤新太郎氏が，この頃 はまだここの研究室におって力をつくされ，また日本 酸素から田代為喜氏，旭化成から松午下禎吉氏らが参 加されて, 大学の研究としてはかなり大がかりのもの となった。とはいっても，この研究の規模は当時金属 材料研究所にあった水素液化機あるいはそのための水 素圧縮機の容量で制限されるべきもので, 大学内での 研究として, あるい忤一段階の実験としては丁度よ い規模であったと扔もう。研究の目標を以下の諸点に おいた。 1）天然の水の電解による水素ガスを原料に してこれを液化し精溜して，重水素（この場合 HD） を 100 倍程度濃縮してみること。2）規模は小さいけ れども，この方法が工業的規模の大きさになったとき に必要なシステムを具備し，また可能な手段を採用寸 ること（たとえばデュワー瓶の上うな高真空熱絶縁法 などは採用しない）3）当時危険視されている液体水 素を化学工学的分離操作の対象とし, 実現してみせる こと。特にこの 3) は当時の原子力委員会の石川一郎 委員長はじめ, 関係者一同不安をもっておられたらし いので, 実際に研究所で水素液化機精溜装置を働かせ て参観してもらった。

この研究は今で桜史的ともいえる古さになった が，水素が将来大量に使われる際に低温工学の寄与市 る分野には役立つモデル的部分をもっていると思える ので，少し述べておく。

1) 水素液化機一従来から設備されていた八イラン ド製の $6 l / h r$ のものは役に立たないので，別に $25 l /$ $\mathrm{hr}$ の液化容量のものを作った。今汃られ机特に之 りたてていら程ではないが，それまでの八イランド製 のものに比して, 熱絶縁, 水素の精製, オルソーパラ の転移装置等新たに工夫した点があり，同じ圧縮機を 使って液化能力は 4 倍以上に京った。2) 熱絶縁一更に 大掛りの工業装置に発展する場合にそなえて，従来低 温実験装置に用いられていた高真空絶縁法はやめて, 粉末充填低真空絶縁法をとった。このため充填物の種 類をスラッグウール，シリカゲル，サントセル等を試 み, 更に粉末の大きさ, 充填密度, 真空度などと熱伝 導倸数との関係をしらべた。その結果, 200 メッシュ
程度のサントセルを充填し 1 0.1 torr 程度の真空で 十分の絶縁を得た。3) オルソーパラ転移装置一水素 の液化する手前の温度で活性炭に水酸化鉄 $\mathrm{Fe}(\mathrm{OH})_{3}$ をしみこませた部分を通過させて大部分の水素をパラ に朊移させて, 液化後のオルソーパラ枟移のための発 熱, 蒸発を防いだ。4）膨張機一コリンズ式へリウム 液化機に用いられている型の膨張機を用いた。直径50 $\mathrm{mm}$, 長さ $118 \mathrm{~mm}$ のピストンで, 高圧側は $50 \mathrm{~atm}$ である。膨張機の効率は $60 \%$ 以上であった。5）精 溜塔一はじめにガラス製の精溜器で予備実験をした。 径 $10 \mathrm{~mm}$, 高さ $380 \mathrm{~mm}$ ，ステッドマン充填片を用い たもので，蒸溜速度と還流比などの試験をした。この 充填塔は HETP $53 \mathrm{~mm}, 7.2$ 段に相当した。予備実 験で水素の重水素 (HD) 濃度 $0.016 \%$ を $1.7 \%$ まで 濃縮できた。本番の全系に組みこんだ精溜塔は，径 $47.8 \mathrm{~mm}$ ，高さ $1,200 \mathrm{~mm}$ の金属製のヘリックス片 充填塔で, 還流比 4, HETP $50 \mathrm{~mm}$ で㚣った。

全体の系を図に示す。寒冷発生系統小水素圧縮機 $\mathrm{C}_{1}$ より熱交換器 $\mathrm{E}_{1}, \mathrm{E}_{2}, \mathrm{E}_{3}$ と液体窒素で泠却され たオルソーパラ転移器 $\mathrm{K}$, 膨張機 $\mathrm{E} . \mathrm{E}$ を子くみ, 水 素ガス $50 \sim 70 \mathrm{~m}^{3} / \mathrm{hr}, 50 \mathrm{~atm}$ で, うち $22 \mathrm{~m}^{3} / \mathrm{hr}$ を E. E に分ける。精溜される原料水素系泣，区縮機 (5 $\mathrm{atm})$ 上り $10 \mathrm{~m}^{3} / \mathrm{hr}$ で熱交換器 $\mathrm{E}_{3}, \mathrm{E}_{4}$ 拉上び液体 窒素泠却器 $\mathrm{L}_{2}$ 亲へて，F上り精溜塔 $\mathrm{RC}$ に人る。䋓 縁箱は二つに区分し, 窒素温度以下の中央部は前記の 粉末充填低真空絶縁を, その外側は単にスラッグウー ル絶縁を行なった。

$\mathrm{HD}$ 約 $2 \%$ に濃縮された液体水素を每時 $90 \mathrm{cc}$ 塔底 より得ている。この濃度より $100 \%$ 付近に濃縮するこ とは非常に容易なことである。

この研究は当時まだ余り外国の情報の得がたい頃に 行なった。1958年の第 2 回国際原子力平和利用会議に 報告したうが，その会では，ドイッ,ソビエットでは すでに中位の工業規模の水素精溜を試験的に進めてい ることが報告されたので，これらを視察できたが，当 時彼我の低温工学あるい性低温工業にはこのくらいの 差があったのである。

\section{3. 水素の爆発の経験}

水素が将来“きれいな燃料”としてあるい梳エネル ギ一媒体として日常的に用いられるためには, その爆 発に対する防止策がとことんまで究明され, 実行され ていなけ机多ならない。たしかに水素の爆発について は真実以上に䀣念されているふしもある。しかし，そ

低温工学 
の酸素との混合ガスの爆発濃度範囲が $5 \%$ から $95 \%$ といら広い範囲であること, 起爆のきっかけとなるエ ネルギーが他のガス爆発の1/10 といら小さいものであ ることは，爆発に対する用心を十二分にせ㸚ばならぬ 科学的理由でもある。一方他の燃料ガスの爆発以上に 恐れなくともよいとする説も見聞するが，この説にも 一面的な根拠もある。筆者は比較的初期加ら自分の水 素液化機を扱い，その液体水素を用いての研究実験を 行なってきた数少ない経験者として，この間に経験し た水素の爆発を思い出してみたい。

a）水素ガス製造のさいの爆発

大学を卒業して初めて金研に勤めた年加ら，液化用 の水素ガス製造の仕事在別の自分の研究のかたわらの 仕事としてやらされた。水の電解で $3 \mathrm{~m}^{3} / \mathrm{hr}$ の水素 を製造する。もちろん液化用であるため，99.9\%以上 の紦度を維持する必要があり，電解発生後タンクに導 く前に精製のためパラヂューム触媒の部分を通す。大 量の水素製造の経験はもちろんないので，シーメンス からの(電解装置はシーメンスからのもの)指導書の通 り一生懸命にやったつもりだったが，最初の電解一発 生の際, この精製部で爆発して, 大きな安全器（直径 $40 \mathrm{~cm}$, 深さ $30 \mathrm{~cm}$ 位の円筒に砂をいれたもの）が吹
き飛んで危い目に会った。今から思えばもちろん初等 的なミスであるが，その指導書には「発生した水素を 分析して 98 以上になったら精製器の部分の加熱用 のスウィッチを入れよ」とあって，そのつもりで精製 器は加熱していなかったが爆発した。つまり，パラヂ ューム触媒は「常温でも」働いて，前記の 45〜950 の爆発範囲内のガスには起爆の働きをしたわけであ る。パラヂューム触媒が完全に新しく処女的な場合は この位有効であつたが，その後は $200^{\circ} \mathrm{C}$ 位の加熱で初 めて衝いた。今日ならばなに忙もあれ，水素を通じ る部分の管内老全部窒素で通気洗條するところであ る。この愚かしい経験圭ここに被露するのは，「起爆 の原因はす心゙てが判明しているのではないかも知れな い」と㧍それるからである。よく静電気が原因になっ て…」などといわれる爆発があるが，これも必ずし もよくわかっているわけではない。水素爆発にかぎら ず，爆発事故のほんとのぎりぎり最初の起爆は科学的 にせん明されないで效策を立てられ，たいていはそれ で済んでいるので解明されたようにみえている。この 対策の網目からもれる原因があるのをおそれねばなら ない。

b ）液体水素のあずかった爆発

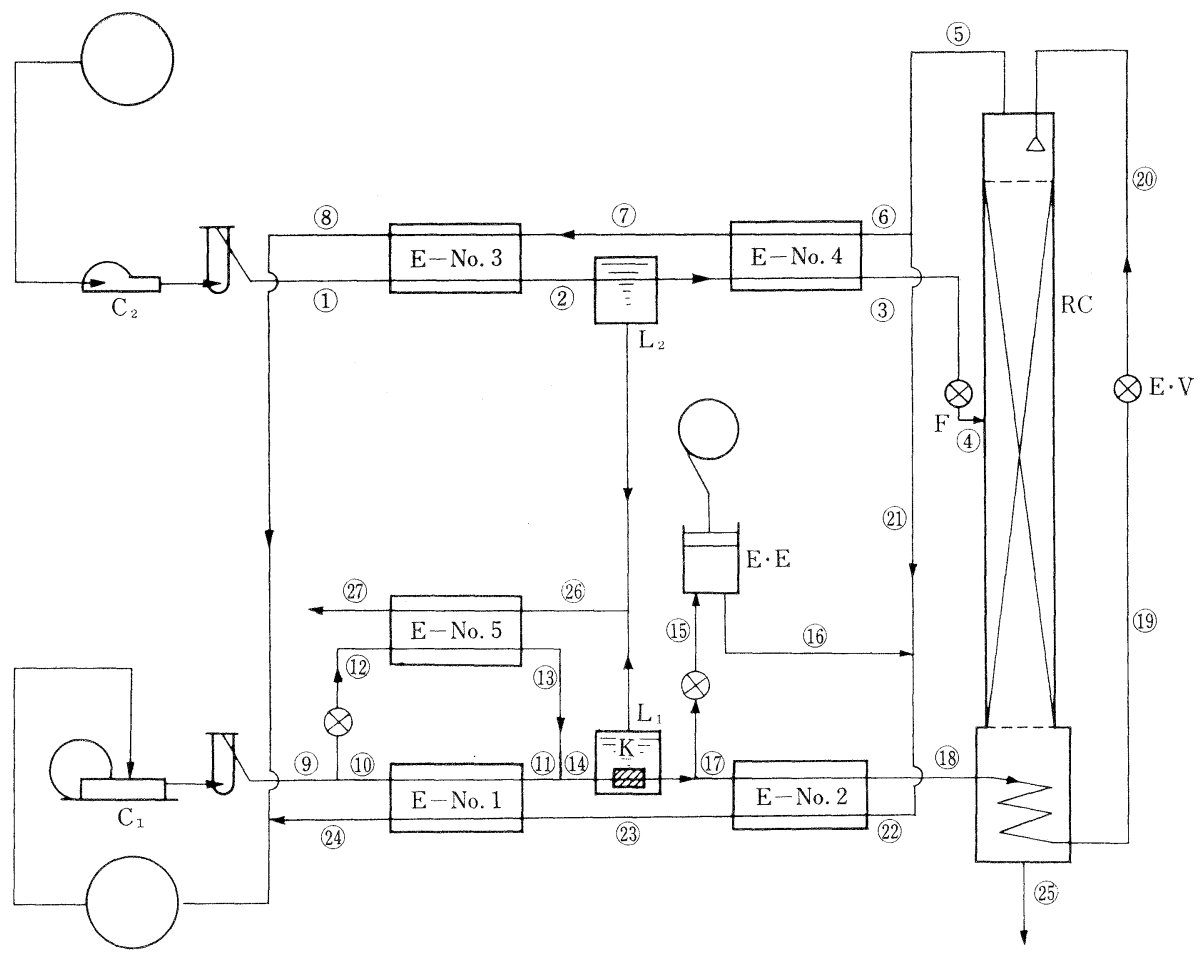

水素精溜装置の系統図

Vol. 8 No. $5(1973)$ 
20年程の間, 自分で水素を液化し, 液体水素をつか っての研究をしてきた。もちろんこの頃の液体へリウ ムを用いての実験のようにひんぱんではなかったが， 液化能力の割合にはガラの大きな水素圧縮機をすぐそ ばで迴しながら液化機を操作することは，心理的にい つも不安を抢ぼえた。もちろんモーターは床面より低 い地下室のようなレべルにはあったが，每回緊張した 気持で液化機に対した。今日ならばもっと安心の出来 る配置と設備がなされるであろう。幸い液化にさいし ては全然事故を㧍こさなかった。また液体水素をつか っての実験でも，前記の水素とフッ素の反応をためす 実験のさい以外には爆発はおこさなかった。必ずしも 液化ガス, 高圧ガスの取り締りが完全でなかった時代 からスタートして，この間よく無事故で経過したもの と,われながら感心している。おそらく最初の電解水 素爆発の経験が身にしみていたために, 自分にも周囲 の人たちにもきびしくかつ細心の注意を集中する習慣 がついたためかもしれない。この間にも，オックスフ ォード大学のクラレンドン研究所で水素液化機の爆発 があったし, MIT の水素泡箱の爆発事故があった。 クラレンドンではそれ以後水素の冷却には液体“窒素” を用いることを览行している。これらの爆発の真因が どの程度解明されたが知らない。当時の知識をも。 てすれば防げたものなのか, あるいはこの事故をギセ イとしてわれわれの知識が子えたのか。

c）その他の例

水素ガスがもれたり, 排除不十分で着火して爆発す る例は二，三見聞しているが，これはわれわれの知識 をもってす机ば確実に防げる事故である。その一例を 記すと，化学の実験室で小さな爆発事故があった。50 $\mathrm{m}^{2}$ ほどの広さの有機化学の実験室でコンクリートの 天井全面でメラメラと水素ガスがもえていた。これは 室の隅に立っていた水素ボンべの安全弁が破れて一気 に水素ガスが吹き出し，実験中のバーナ一などで着火， 爆発したのだが，広い室であったため機械的な破壞は なく，いち早く天井に上昇した水素ガスが一面に然え る程度で終った。ボン心゙の安全弁が完全ならばおこら なかった事故である。この例でもわかるよらに，水素 の爆発の場合，水素ガスの大部分はいち早く上に昇っ て,全部のガスが爆発反応に参加しないケースが多い。 これは水素の爆発事故を場合によっては軽微なものに している原因であ万う。しかし，これも，も机出す水 素ガスの量と，囲まれた室の大きさや状況によるもの で，だい分前におきた川崎地区の硫安工場での水素爆
発のような大事故もある。いずれにしてもこの種の事 故は, 管理, 保守, 操作のルールを完全に守机ば確実 に防止できるものであるう。

\section{4. 関連する物質の探究}

将来の水素の工業的需要に関連ある物質, 特に低混 科学, 低温工学の分野で関連ありそうな物質の探究が, 内外で静かに行なわれている。静かにというのはいま だ花々しい成果とまでいっていないからである。筆者 も関心をもちつづけ，あるい忙その部を手がけてき たもので, 今後わが国でも着手してほしいものである。

a) 水素収容物になる化合物 ${ }^{6}$

水素が燃料劣るいは土ネルギー媒体として用いられ る場合, その貯蔵や運送はガスタンク, 液化ガスタン クや管送あるいは液化ガス運搬容器が用いられるだる う。これは今日の LNG や液体酸素, 液体へリウムの 場合と似ている。近時, ある種の物質は水素と結合し また放出することが比較的容易に，温度のコントロー ルでできることがわかって，これが水素の収容器の役 目をするのではないかと注目され，研究されている。 オランダのフイリップスの研究所で $\mathrm{LaCo}_{5}$ など稀土類 $(\mathrm{R})$ と遷移金属 $(\mathrm{M})$ との金属間化合物 $\mathrm{RM}_{5}$ が強磁 性材料として非常にすぐれたもので㐫ることをみつ け，いろいろ研究しているらちに水素に対する特異な 性質を発見した。たとえば $\mathrm{LaNi}_{\text {。 }}$ は約 $80^{\circ} \mathrm{C}$ で $15 \sim$ $20 \mathrm{~atm}$ の平衡圧のもとで水素を吸収あるいは放出す る。 $20^{\circ} \mathrm{C}$ ではこの平衡圧は $2 \sim 3 \mathrm{~atm}$ である。 $\mathrm{LaNi}_{5}$ $\mathrm{H}_{6}$ 付近の割合まで水素を吸収するから, 水素の收容 器にもなるし,また温度を調節操作することによって, 一種の水素圧縮機的銜きもできる。もちろんこのよう な物質が水素の収容器や圧縮機に適するにはいろいろ な条件があるうが， $\mathrm{RM}_{5}$ 型化合物の他の種々の物質 $\left(\mathrm{Mg}, \mathrm{Mg}_{2} \mathrm{Ni}, \mathrm{V}, \mathrm{NaAl}\right.$ 化合物等 $)$ についても方々 で探究されつつある。

b) 高温超伝導体の探求

ここに高温というのは液体へリウムより高い温度を 意味しているつもりである。へリウム温度では十分実 用になる超伝導体はすでに膨大な用途を期待されてい る。しかし常温とまで法いかなくと液体空気温度, せめては液体水素温度で用いらる超伝導体があ九ば, 格段に実用性をますことは明らかである。早くから， 理論的に超伝導の $\mathrm{T}_{\mathrm{c}}$ は $20^{\circ} \mathrm{K}$ あたりが上限であると となえられ，現に $\mathrm{Nb}_{3} \mathrm{Al}_{0.5} \mathrm{Ge}_{0.2}$ に括ける $\mathrm{T}_{\mathrm{c}}=20.7$ ${ }^{\circ} \mathrm{K}$ 以後数年を一ても，まだこの $\mathrm{T}_{\mathrm{c}}$ を越すものが出 
ていない。しかし物性理論家の $\mathrm{T}_{\mathrm{c}}<20^{\circ} \mathrm{K}$ 説の精度 はそれ程確たるものではなからら。 $\mathrm{T}_{\mathrm{c}} \approx 25 \sim 30^{\circ} \mathrm{K}$ と なっても不合理ではない程度のものであろら。新しい 超伝導物質の発見, あるいは製作に独占的な寄与をし てきたアメリカの B.T. Matthias は, “金属的化合物 の結晶構造や電子密度の点で有利なものがみつかれば T c が $25 \sim 30^{\circ} \mathrm{K}$ にもなりえて, 工業技術的革命が果 たされるだろう”といったこともあり，この方向で新 しい超伝導体を探究している研究グループがある。こ のような材料探究は多大の人数と時間を要する仕事で あるが, 正しい理論的方向付けをともなって進めて成 功すれば, 技術的革命をもたらし, ヘリウムにかわっ て水素が低温媒体となるかもしれない。

高温超伝導体は上記の金属における電子一格子相互 作用に原因するものの他に，エキシトン機構によるも のがアメリカの W.A.Little, ソビエットの V.L. Ginzburg らによって提唱され， $\mathrm{T}_{\mathrm{c}}>100^{\circ} \mathrm{K}$ も不可能 ではないといわれているう。しかしこの種の考えられ るモデルは一次元的あるいは二次元的導体であるの で, 統計力学的立場からの理論家の強い反論もある。 三次元的な完全な超伝導体にはなり得なくとも, 超伝 導電子の “ゆらぎ”により電気抵抗ゼロに漸近するこ とは可能であると推論されて，この方向への実験的研 究を推進しているグループもある。この努力もここ数 年来実らず，悲観的になりかけていた最近，A.J. Heeger $5^{8)}$ が TCNQ (tetracyanoquinon) 系統の有機 半導体を研究していて, TTF-TCNQ (dimethyltetrathiofulvalene tetracyanoquinondimethane) の電気 伝導が $60^{\circ} \mathrm{K}$ 付近で急に 500 倍程度になることをみつ け，これを超伝導転移のあらわれと考えた。これがは たして起伝導のあらわれであるかどらか今後問題のあ ることであろらが，この現象の発見は有機超伝導体を 探究する人達を大いに元気つけけたことであるう。

この種の努力はついに不成功に終れば，オルソドッ クスな理論を無視した愚行とそしる人も出よらし, も し成功すれば理論家頼むに足らずとなろう。科学の進 歩飛躍の過程でこのようなことはくりかえされるもの であろう。

c）金属水素の問題9”

この問題は将来低温工学につながるかどうかわから ないが，水素に関することなので言反しておく。固体 水素に超高圧を加えると, 分子性結晶から金属結晶に なること，また別にこの金属水素は $200^{\circ} \mathrm{K}$ 程度の超 伝導転移点をもつことが理論的に推測されている。こ
の理論よりうる数值（必要な高圧力の大きさや $\mathrm{T}_{\mathrm{c}}$ の 值）はもち万ん甚だ不確かであるが, 本質的なこの傾 向は確からしい。必要な圧力は 100 万気压前後と推定 されていて, 今日この超高圧は実験的に実現可能にな ったので，上記の理論的推測をためそうとの計画がア メリカをはじめ方々でスタートした。200 $\mathrm{K}$ 程度の $\mathrm{T}_{\mathrm{c}}$ は前記の高温超伝導の可能性を期待させるが， 100 万気压の圧力を除くともとの安定な分子性結晶（非金 属性）にもどるはずであるから，実用にはならない。 しかし, 準安定状態として, 若干時間（甚だ不確かな 推論しかない) 金属水素, 超伝導体としてとどまる。 このような見达みなので実用に程遠いかもしれない が，この研究が引き金となって高温超伝導体の進路が また開けるかもしれない。なお金属重水素は，高圧を 除いたあとの準安定状態の寿命が十分長い見とおしも ある。

\section{5. 水素時代に向かっての低温工学の集備}

最初に記した, 水素をエネルギー源, あるいはエネ ルギー媒体として用いられる時代が一挙にはこないに しても, 段階的に（現にロケットの推進剤として液体 水素を用いることが始まっている) 焦むであろら。ま た少し長い目でみれば, 化石燃料源がつぎつぎと新た にみつかっても需要に追付け始ようになるが如く， ヘリウムガス源もまだまだ新しいのが発見されよう が，いずれは大気にもどってしまって，これまた欠乏 時代が同様に来るだろら。もっともこちらの方はその うちに重水素の融合反応在現実化できて, ヘリウムを どんどん作るようになるかもしれないが。水素エネル ギーシステムの時代が “数”十年後（この“数”がい くつかはわからないが）に来るのにそなえて，低温工 学はどら対処しておくべきか。へリウムのよらに冷媒 として用いる他に, きわめて大量に消費される水素圭 液化し, 貯蔵することになる。技術的には液体へリウ ムと液体酸素，あるいはLNGの雨面をかね敉をなえね ばならないだろら。液体へリウムの技術と同様に空気 在凝縮する構造はさけねばならないし, LOX や LNG の場合のように大量の液化ガスを容れ，流し，また蒸 発させる構造と技術を要求される。へリウムの場合, その漏えいは熱絶縁を悪くするが，水素の場合はその 上に爆発の传険もある。要するにLOX 製造装置位の 規模のものに一リウム液化機程度の精密さ要求され るだろら。ヘリウムの技術も LNGなどの技術も, 共 に今後さらに完成されるだろらから，この両者を結合 
させれば水素の時代にもおおむ間に合うであろう。 あえて異なる点をあげれば，水素の場合に法水素の液 体と固体の共存した状態（スラッシュ）を取り扱うこ とがあるかもしれない。これは必ずしも平衡状態のみ でなく，非平衡的にこの状態にあるものを貯えたり， 流送したりするかもしれない，この技術はへリウムの 場合にはありえなかった。

次に，くりかえすようだが，水素の爆発の伦険を防 止する技術を作り上げねばならない。これは一つ一つ の装置の構造設計の上に, また操作の上に実現させね 壮ならない。よく「水素の爆発の危険性はさほどでも ない」とか，「真実以上に過大視されている」とかい われている。前項にも書いたように, 水素洼軽いが故 に危険の度合いが少なく，また有毒ガスの発生も少な くてすんでいることも事実であるが，反面，もれやす く, 混合ガスの爆発範囲が広く, 爆発のキッカケのエ ネルギーが小さいことは矢㖘り警戒に值する。一般の 危険感を軽減して, 安心して水素燃料の飛行機に乘り, 家庭で水素燃料電池を用いるようになるには，防爆技 術の完成をみせて納得してもらうことであろう。

なお水素の場合考慮しておか补ばならないのは，材 料の水素脆性である。低温にのみある部分はよいとし て，エンジン部分や压力変化の大きい部分は材料の選 択に慎重を要するであるら。これはそれ程むつかしい 問題ではないが，水素特有のことである。

最後に, 低温工学として重大な考慮を要する問題は 超伝導とのかねあいである。前記の高温超伝導体はさ ておいても, なお現在重要視され，期待されている超 伝導の電力機器と送電への応用は, 水素エネルギーシ ステムとはいずれかの時点で競合する部面があるだろ
う。両方ともまだ成長していないものだけに（もちろ 儿超伝導の方に十数年の長はあるわけだが), 今から 科学技術のみならず, 更に広い高い立場で時日をかけ て検討する必要があるだろう。

\section{参考 文 献}

1) 太田時男：物性, 13 (1972) 405, 低温工学 8 (1973) 52 など

2) 菊池一成 : 低温工学, 4 (1969) 26

3) E. Kanda, Bull. Chem. Soc. Japan 13 (1938) 241

4) E. Kanda, Bull. Chem. Soc. Japan, 12 (1937) 521

5) E. Kanda, S.Sato, T.Sato, G. Monna, T. Tashiro, M. Kubota, T. Matsugashita; Proc. 2nd UNIC Pecaful Uses of Atomic Energy (1958)

6) J.H.N. van Vucht, F.A.Kuijpers \& H. Bruning; Phillips Research Reports 25 (1970) 133

その他 C. Marchetti; Chemical Economy and Engineering Review (CEER) 5 (1972) 7 の review paper references 中に多数ある。

7) W.A. Little; Phys. Rev. A 134 (1964) 1416, VL. Ginzburg : Contemp. Phys. 9 (1968) 355, V.L.Ginzburg, D. A. Kirzhnits : Rep. 4 (1972) 343

8) L. B. Coleman, M. J. Cohen, D. J.Sandman, F.G. Yamagishi, A.F. Garito \& A.J. Heeger; Solid State Comm. 12 (1973) 1125

9) N.W. Ashcroft; Phys. Rev. Letters 21 (1968) 1748, G.F.Chapline; Phys. Rev. B 6 (1972) 2067, E. E. Salpeter; Phys.

Rev. Letters 28 (1972) 560，これらに古い文 献もある。 